\title{
The Development of MOOC and Its Impact on Higher Education in China
}

\author{
Hua-liang LU*, Hui-ying HUANG and Qiu-yu YE
}

School of Business Administration, Nanjing University of Finance and Economics, Nanjing, China

${ }^{*}$ Corresponding author

Keywords: MOOC, Higher Education, Reform, China.

\begin{abstract}
The rise of MOOC changes the way of higher education in China and worldwide. This paper introduces concept and the development of MOOC in China, followed by the explanation of the educational feature of MOOC. This paper ends with the impact of MOOC on higher education in China.
\end{abstract}

\section{The Rise of MOOC}

The term MOOC refers to Massive Open Online Course. Wikipedia defines MOOC as "a large, open, online course for the general public through the Internet." Professor Jiao from South China Normal University initially translated MOOC into Chinese [1]. This translation has been widely accepted in China.

The development of MOOC has gone through a long process of accumulation. In the 1960s, Douglas Engelbart of the United States proposed a plan to change the existing education system with computer technology. In 2007, American scholar David Wiley developed a course based on Wiki, named "Introduction to Open Education". Through the Internet, this course teaches learners all over the world, and allows learners to provide a large amount of information and content for the course. Thus learners become the constructor of the course as the same time. In 2008, Stephen Downes and George Siemens in Canada opened the course "Connectedness and Linkage", this course supports large-scale online learning and also uses the way learners build courses together, attracting a large number of learners worldwide and to become the world's first MOOC course. Since then, many elite universities worldwide have joined this MOOC wave.

\section{The Development of MOOC in China}

The development of MOOC in China are highly supported by Chinese government. In 2000, the Higher Education Department of the Ministry of Education launched the pilot project of "New Century Online Curriculum Construction", with the goal of building about 200 online courses, case bases and test banks in about two years period and providing the required network learning resources for modern distance education. As of 2004, 299 projects had passed the evaluation. Many online courses have been widely used in online education institutes. In 2003, the Ministry of Education launched "National Excellent Courses Construction Project", which is open to all undergraduate colleges, vocational colleges, online education institutes and others institutions across China. From 2003 to 2010, after 8 years development, about 3800 courses have been evaluated and approved as national high quality courses. The Ministry of Education launched the "National Excellent Curriculum Construction Project" in 2011, including excellent video open courses and resource sharing courses, which is upgraded based on the original national high quality courses. From 20112013, a total of more than 200 well-known universities and colleges participated in the high quality video open course construction. Among them, more than 120 courses were open to public (Ministry of Education, 2014).

In 2012, MOOC "Digital Tsunami" swept the world, and Chinese universities have been joining MOOC construction practice since early 2013. There are four different ways for China's universities and colleges participating in MOOC: joining the international MOOC platform, building Chinese MOOC platform, forming inter-university MOOC alliance, and organizing MOOC forums. 


\section{Joining the International MOOC platform}

Join the international MOOC platform is the first reaction of Chinese universities to the international MOOC movement, which can be seen as the performance of our country's colleges and universities participating in the initial MOOC practice. Between 2013 and 2014, Peking University and Tsinghua University announced that they have joined the edX platform and together with the University of Hong Kong and the Hong Kong University of Science and Technology, have become the first university members in Asia to sign edX. Fudan University, Shanghai Jiaotong University, Chinese University of Hong Kong, and National Taiwan University have signed cooperation agreements with Coursera platform. Shanghai Jiao Tong University, Fudan University and the UK online learning platform Future Learn reached a cooperation intention.

\section{Building Chinese MOOC Platform}

Another important manifestation of the MOOC practice in colleges and universities in our country is to build our MOOC platform. In October 2013, Tsinghua University built the first MOOC platform in the world by using edX open source code. The platform has attracted more than 50,000 participants from the world for two months. In 2014, Jilin University introduced "Jida Online School" and Shandong Agricultural University launched "Shennong Online". In 2015, Peking University collaborated with Alibaba to launch the "Mandarin Chinese Course" platform.

With the deepening of MOOC practice activities in colleges and universities, MOOC platform construction and course development craze have been launched in China. In view of the "education craze" that emerged in our country in 2014, the domestic media described 2014 as "the first year of MOOC in China."

\section{Forming Inter-University MOOC Alliances}

As China's colleges and universities continue to strengthen exchanges and cooperation, through the integration of high-quality inter-school resources, the establishment of a curriculum sharing mechanism to create inter-school MOOC alliance. For example, in 2012, the Shanghai Municipal Board of Education led the establishment of the "Shanghai University Curriculum Center" and invited 30 local colleges and universities in Shanghai to join these institutions to promote inter-school elective courses and credits. In 2013,Shanghai Jiaotong University, Xi'an Jiaotong University, Beijing Jiaotong University, Southwest Jiaotong University and Taiwan's National Chiao Tung University jointly launched the "ewant Open Education Platform" (ewant) to free the core courses of the five universities. Chongqing University led the eastern part of colleges and universities set up a joint "eastwest college course sharing alliance." In 2014, Shanghai Jiao Tong University took the lead in setting up the MOOC alliance platform "Top Universities Online" in China's top universities, and promoted mutual recognition of MOOC credits at 19 universities in southwest Shanghai. Shenzhen University took the lead in establishing the UOOC alliance to achieve an effective connection with local undergraduate education.

\section{Organizing MOOC Forums}

Our colleges and universities also actively devote themselves to MOOC academic seminars and organize various forms of MOOC forums. In June 2013, Tsinghua University launched the first MOOC forum in China, opening the curtain of MOOC research in our country. The conference discussed the impact of MOOC on China's higher education and how colleges and universities should deal with MOOC challenges. In July 2013, Shanghai Jiaotong University launched the "International Forum on Online Education Development (MOOC)" and discussed issues such as building a highlevel MOOC platform in China. In October 2013,the "China Computer Conference" held in Changsha also held a special forum on the topic of MOOC, and the experts participating in the conference conducted in-depth discussions on the MOOC future development trend and application of MOOC education. 


\section{The Pedagogical Features of MOOC}

Through the comparison of traditional classrooms, first-generation online courses and MOOC (see Table 1 below), we can found several distinguish feature of MOOC. First, in the pedagogical approach, MOOC adopts short video and small-scale procedural instruction. Second, in the learning evaluation mechanism, MOOC adopted an embedded quiz, highlighting the importance of procedural evaluation. Third, in the knowledge construction process, MOOC participants conducted online interactive learning through the formation of a community. Throughout the learning process, learners occupy a central position. Therefore, MOOC learning is a kind of highly conscious and initiative socialized learning. Learners are the "masters" of learning activities. Teachers are the assistants and service providers of the learning process.

Compared with the traditional classroom teaching mode, the relationship between "teaching" and "learning" has been reversed and the occurrence of constructive meaningful learning has been promoted.

Table 1. Comparison of traditional course, the first generation network course and MOOC

\begin{tabular}{|c|c|c|c|}
\hline & Traditional courses & $\begin{array}{l}\text { The } 1^{\text {st }} \text { generation of online } \\
\text { courses }\end{array}$ & MOOC \\
\hline Tuition & Yes & No & No \\
\hline Number of courses & $\begin{array}{l}\text { There is a limited choice } \\
\text { of courses }\end{array}$ & Unlimited & Unlimited \\
\hline Course type & $\begin{array}{l}\text { Professional courses }+ \\
\text { Public Courses }\end{array}$ & Unlimited & Unlimited \\
\hline $\begin{array}{l}\text { Time and space } \\
\text { constraints }\end{array}$ & $\begin{array}{c}\text { Need to specify the } \\
\text { place at the designated } \\
\text { time class }\end{array}$ & No & $\begin{array}{l}\text { Have periodic discussion } \\
\text { and homework }\end{array}$ \\
\hline Learning rhythm & Teacher control & Student control & Student control \\
\hline Class hour & About 45 minutes & About 45 minutes & About 2-20 minutes \\
\hline Student size & Small scale & Support large-scale & Support large-scale \\
\hline register & $\begin{array}{l}\text { Need to register as a } \\
\text { student of this school }\end{array}$ & No registration required & $\begin{array}{l}\text { Need to register as a } \\
\text { platform member }\end{array}$ \\
\hline Course content & Fixed & Fixed & Generated \\
\hline Teaching mode & Teacher-centered & Teacher-centered & Student-centered \\
\hline class interaction & $\begin{array}{l}\text { Most interaction for } \\
\text { teachers and students }\end{array}$ & No interaction & $\begin{array}{c}\text { Teacher-student } \\
\text { interaction、Student- } \\
\text { student interaction }\end{array}$ \\
\hline $\begin{array}{l}\text { Interaction under } \\
\text { class (under line) }\end{array}$ & Basic None & No & $\begin{array}{c}\text { Teacher-student } \\
\text { interaction、Student- } \\
\text { student interaction }\end{array}$ \\
\hline Class exercises & Some courses have & No & Yes \\
\hline Learning feedback & Classroom solution & No & $\begin{array}{c}\text { It can be solved in class and } \\
\text { under class }\end{array}$ \\
\hline Evaluation mode & $\begin{array}{l}\text { Normal grade }+ \text { final } \\
\text { exam, basic to teacher } \\
\text { assessment }\end{array}$ & No & $\begin{array}{c}\text { Software Based Quizzes, } \\
\text { Assignments, Problem Sets; } \\
\text { Teacher Assessment; } \\
\text { Student Mutual Evaluation }\end{array}$ \\
\hline $\begin{array}{l}\text { Inter-school } \\
\text { cooperation }\end{array}$ & Basic None & No & Yes \\
\hline Credit certification & Yes & No & Yes \\
\hline
\end{tabular}

Source: [2].

\section{The Influence of MOOC on China's Higher Education}

\section{Promoting the Transformation of Teaching Philosophy}

The traditional university teaching in our country focuses on teachers and teaching materials and classrooms. It focuses on the teaching of knowledge theory but lacks interest in students' interests and needs. However, the rise of MOOC is overturning the traditional teaching concept. MOOC carefully organizes and presents the course content based on students' interests and needs. For example, each 
lesson usually takes 10-15 minutes. The reason is that after a certain period of time, students' attentiveness will decline and the rise of MOOC makes students return to the main position of learning and teaching [3].

\section{Promoting Continuous Learning of Teachers}

The rise of MOOC poses a challenge to the knowledge reserve and university teaching of university teachers in China. MOOC is also forcing university teachers to adopt new teaching methods and techniques to improve teaching effectiveness and learning efficiency. Otherwise, teachers based on traditional university teaching will be eliminated by students; Universities that adopt traditional teaching methods also face the danger of losing their markets [4].

\section{Promoting Students' Diversified Learning}

Making use of the convenience of MOOC to form the teaching mode of "+MOOC" in class. Teachers can guide students to learn high-quality courses above MOOC platform, broaden students' knowledge. Curriculum diversification is not only reflected in the form of teaching. For the same content of the same course, MOOC has unique insights from different experts. Students can choose different teachers' courses for repetitive learning, which helps students to diverge their thinking and broaden their knowledge [5].

\section{Breaking the Limit of Credit Certification}

Credit certification is an authoritative certification of MOOC learning outcomes. Although students can obtain the corresponding credit certificate through studying MOOC course, there will be some problems if the student's MOOC credit can be approved by the school. Therefore, how to break the limit of credit certification, schools need to research and propose docking measures in time so as to clear the obstacles for students to participate in MOOC learning [6].

\section{Acknowledgement}

Authors are grateful to the financial support from Natural Science Foundation of China (71773046), Jiangsu Social Science Foundation (16HQ014), Higher Education Philosophy and Social Science Research Fund of Education Department of Jiangsu Province (2017ZDIXM061), The Higher Education Reform Research Project of Jiangsu Province (2015JSJG035) The 13th 5-year Key Project of Jiangsu Education Science (B-b/2016/01/23), Qing Lan Project of Higher Education of Jiangsu Province and Six Talent Peak Project of Jiangsu Province.

\section{References}

[1] X. CHEN, MOOC's development history and main characteristics analysis, Modern Education Technology, 2013, 23(11):5-10.

[2] J. WANG, Y. FENG, Y. WANG, Cold thinking behind MOOC fever, Educational Research, 2014 (9):104-111.

[3] W. FAN, MOOC learning achievement certification and its impact on the path of higher education reform, Modern Distance Education Research, 2015(3): 53-64.

[4] E. J. EMANUEL, Online Education: MOOCs Taken by Educated Few. Nature, 503(342), 2013.

[5] Z. HUANG, X. DU, Influence of MOOC on College Student Learning and College Teaching: A Survey Based on Three University Students in Zhejiang Province, Modern Education Management, 2016 (2):56-61.

[6] E. J. EMANUEL, Online Education: MOOCs Taken by Educated Few. Nature, 503(342), 2013. 